\title{
Is tagging with visual implant elastomer a reliable technique for marking earthworms?
}

\author{
Kevin Richard Butt(1), Maria Jesús Iglesias Briones ${ }^{(2)}$ and Christopher Nathan Lowe ${ }^{(1)}$
}

\begin{abstract}
(1)University of Central Lancashire, School of Built and Natural Environment, Preston, PR1 2HE, United Kingdom. E-mail: krbutt@uclan.ac.uk, cnlowe@uclan.ac.uk (2)University of Vigo, Department of Ecology and Animal Biology, 36310 Vigo, Spain. E-mail: mbriones@uvigo.es
\end{abstract}

\begin{abstract}
Visual implant elastomer (VIE) has recently been employed to investigate different aspects of earthworm ecology. However, a number of fundamental questions relating to the detection and positioning of the tag, its persistence and potential effects on earthworms remain unknown. Seven earthworm species belonging to three ecological groupings, with different pigmentation and burrowing behaviour, were tagged using different coloured VIE. External inspection after two days, one week and 1, 10 and 27 months were followed by preservation, dissection and internal inspection. Tags could be seen in living specimens to 27 months, and dissection revealed that in most cases they were lodged in the coelomic cavity, held in place by septa. However, over longer time periods (more than two years), the chlorogogenous tissue tended to bind to the tags and made external observation increasingly difficult. Migration of the VIE material towards the posterior of the earthworm and potential loss of the tag were only observed on rare occasions, and a recovery rate in excess of $98 \%$ was recorded. By introducing a reasonable amount of VIE into segments, just after the clitellum, this technique can become a valuable tool in earthworm ecology and life history studies, particularly in short-medium term laboratory and field experiments.
\end{abstract}

Index terms: capture-mark-recapture methods, chlorogogenous tissue, longevity, Lumbricidae, population monitoring.

\section{A etiquetagem de minhocas com implante visual de elastômero é uma técnica confiável?}

Resumo - O implante visual de elastômeros (VIE) tem sido recentemente utilizado para estudar diferentes aspectos da ecologia de minhocas. Entretanto, questões fundamentais relacionadas à detecção e posicionamento da etiqueta, sua persistência e efeitos potenciais nas minhocas permanecem desconhecidos. Sete espécies de minhocas, pertencentes a três grupos ecológicos, com diferentes pigmentações e comportamentos de escavação de galerias, foram etiquetadas com VIE de diferentes cores. Procedeu-se à inspeção externa depois de dois dias, uma semana e 1, 10 e 27 meses, seguida de preservação, dissecação e inspeção interna. As etiquetas puderam ser vistas em espécimes vivos até 27 meses após a aplicação, e a dissecação revelou que, na maioria dos casos, elas estavam alojadas na cavidade celômica, seguras no lugar por um septo. Entretanto, depois de longos períodos (mais de dois anos), o tecido cloragógeno tendeu a ligar-se às etiquetas e a dificultar a observação externa. A migração dos VIE para a parte posterior da minhoca e a potencial perda da etiqueta foram raramente observadas, e o índice de recuperação passou de $98 \%$. Pela introdução de uma quantidade razoável de VIE nos segmentos logo após o clitelo, esta técnica pode constituir-se em um instrumento valioso em estudos da ecologia e do ciclo de vida das minhocas, particularmente em experimentos de curto e médio prazo, em laboratório e em experimentos de campo.

Termos para indexação: métodos de captura e marcação, tecido cloragógeno, longevidade, Lumbricidae, monitoramento de populações.

\section{Introduction}

Capture-recapture methods were originally developed in wildlife biology to census mobile animal populations, such as birds, fish, and insects (Southwood \& Henderson, 2000). Soil biota and earthworms (Annelida, Oligochaeta), in particular, live in an opaque environment, which makes it difficult to obtain reliable information on their population dynamics, burrowing behaviour and migration capabilities, without adversely disturbing the animals and their habitat. Marking earthworms using chemicals has been attempted with limited success. Mazaud \& Bouché (1980) used coloured dyes to stain animals before releasing them 
into pasture soils to study population size and dispersal rate, but these water-soluble dyes persisted for only a few months. More recently, Dyckmans et al. (2005) described a simple isotope tracer technique for earthworms, but this too was relatively non-persistent, as rubidium was assimilated from spiked soils by Aporrectodea turgida (Ben Hamou et al., 2007). Importantly, no information is available on the potential effects that these chemicals could have on the earthworms, and on whether these marking techniques are tolerated by the animals without altering their behaviour and physiology.

One innovative option for tagging earthworms appears to be the use of commercially available visible implant elastomer (VIE) produced by Northwest Marine Technology (NMT) Inc., Washington, USA. The company suggest that the pliability of the VIE tags, the small volume of material required to make a visible tag, and its tendency to occupy available space rather than displace and irritate surrounding tissue combine to make VIE usable in small organisms (Northwest Marine Technology, 2008). These tags, already successfully used with fish and marine invertebrates (Godin et al., 1996; Brennan et al., 2005), are made from a biologicallycompatible polymer supplied in liquid form that cures into a soft, stable material. The VIE is obtained as two liquid components, which can be injected into the animal using a hypodermic needle, after mixed. Tags are visible to the naked eye, if deposited in unpigmented tissue (Butt \& Lowe, 2007), but if in pigmented tissue, fluorescence in the tag can be seen using a LED blue light source.

Furthermore, previous studies have shown that tags of this kind remain in the earthworm body for at least a few months. González et al. (2006) found that, in forest and pasture soils, tags injected into Pontoscolex corethrurus housed in PVC tubes could be located after a period of four months. Our own provisional field data also showed that a 10 and $20 \%$ recovery of tagged Lumbricus terrestris was obtained from free ranging animals and from those within a $1-\mathrm{m}^{2}$ enclosure, respectively, after a period of five months (over winter), in Brown Forest soils in Scotland. Laboratory studies with a number of temperate earthworm species (Butt \& Lowe, 2007) determined that the tags remained in the animal and could be visually located after a period in excess of 12 months. Importantly, tagging was also shown not to affect growth to maturity, mating or production of viable cocoons of $L$. terrestris under controlled laboratory conditions. VIE tags were shown to be a persistent, cost effective and non-toxic method for marking earthworms. This technique therefore appears to offer opportunities for capture, mark and recapture studies plus more general earthworm longevity records under a variety of field and laboratory conditions.

Additional data (González et al., 2006; Butt \& Lowe, 2007) have, however, suggested that once injected, VIE tags may move within the earthworm body, over time, migrating towards the posterior end and can be "lost" from the tagged animal. In addition, in a small number of cases, Butt \& Lowe (2007) reported that tag integrity changed once administered, and a single unit became a series of slightly dispersed sub-units.

The work described here provides a new step forward in determining the suitability of VIE tagging techniques in earthworm ecological studies, by: establishing the exact location of the VIE material, once injected into the earthworm, and where it becomes positioned in relation to point of injection; identifying the attributes of the VIE material which might change over a variety of timescales within the earthworm body; and investigating whether the species of earthworm and its ecological grouping, in combination with the colour of the tag, might have an effect on the fate of the tag.

\section{Materials and Methods}

Table 1 shows the range of earthworm species and colours of VIE tags utilised in this work. A standard method of tagging, i.e. one injection into a segment posterior to the clitellum, was utilised. Each earthworm, taken from established cultures in the laboratory, was rinsed in water, blotted dry and held between finger and thumb of one hand beside the desired tagging position. A short application of VIE was then administered in less than three seconds making use of the "manual elastomer injector". Replicates $(\mathrm{n}=12)$ of anecic (Aporrectodea longa and L. terrestris), epigeic (Eisenia andrei and

Table 1. Earthworm species and tagging details.

\begin{tabular}{lccr}
\hline Earthworm species & $\begin{array}{c}\text { Ecological } \\
\text { group }\end{array}$ & Length of time tagged & Tag colour \\
\hline Allolobophora chlorotica & Endogeic & 27 months & Yellow \\
Aporrectodea caliginosa & Endogeic & 27 months & Yellow \\
Aporrectodea longa & Anecic & 2 days, 1 week, 1 month & Green \\
Eisenia andrei & Epigeic & 2 days, 1 week, 1 month & Green \\
Eisenia veneta & Epigeic & 2 days, 1 week, 1 month & Green \\
Lumbricus terrestris & Anecic & 2 days, 1 week, 1 month & Black \\
Lumbricus terrestris & Anecic & 27 months & Yellow \\
Octolasion cyaneum & Endogeic & 2 days, 1 week, 1 month & Black \\
Octolasion cyaneum & Endogeic & 10 months & Red \\
\hline
\end{tabular}


E. veneta) plus endogeic (A. caliginosa, Allolobophora chlorotica, and Octolasion cyaneum) species were systematically tagged. These animals were, then, maintained individually under optimal laboratory conditions in labelled pots (Butt \& Lowe, 2007). After 2 days, 1 week, 1,10 and 27 months, four individuals of each species were preserved and dissected under a SZX12 Olympus microscope to determine information on VIE location and integrity.

\section{Results and Discussion}

Through extensive trials, the tagging operation has now been developed and has addressed many of the problems identified by Butt \& Lowe (2007), with respect to delivery of a measured amount of VIE into a desired position in the earthworm. Dissection of the animals showed that delivery is not, as suggested by Butt \& Lowe (2007), into the muscle tissue, but is rather through the muscle wall into the coelomic cavity of the animal. In all but one of the earthworm specimens (E. andrei) used in short-term tagging (two days, one week, and one month), the tag was successfully located. Therefore, over this time scale, a recovery rate in excess of $98 \%$ was recorded. Nevertheless, field results have shown that recovery rates may be much lower, ranging from only $70 \%$, after two weeks in tubes (González et al., 2006), to $10 \%$ after five months in open grassland. It is, therefore, suggested that prior to field experimentation, tagged animals may need to be maintained in culture for a short period to assess their viability.

Tag colour can greatly assist visibility and is best contrasted with the level of pigmentation in the earthworm. The use of green VIE was particularly vibrant in the two red pigmented Eisenia species; for example, the tag could be clearly seen through the body wall of $E$. andrei one month after tagging. After dissecting the animals, it was possible to determine the exact position of the tag as a single rounded unit, nestling in a non-intrusive manner beside the gut (Figure 1). No problems were experienced with exterior observation of tags, in all but one of the earthworm specimens tagged and preserved after periods of two days, one week and one month (Table 1). Similarly, the red VIE could also be clearly seen through the light coloured body wall of $O$. cyaneum tagged for over 10 months, but dissection revealed that the tag presented some adhering nephridial tissue (Figure 2).

In the case of the green pigmented A. chlorotica, tagged 27 months earlier, the yellow VIE colouration was still clearly visible through the body wall (Figure $3 \mathrm{~A}$ ). Similar viability of the tags was also observed for the anecic earthworm $L$. terrestris and

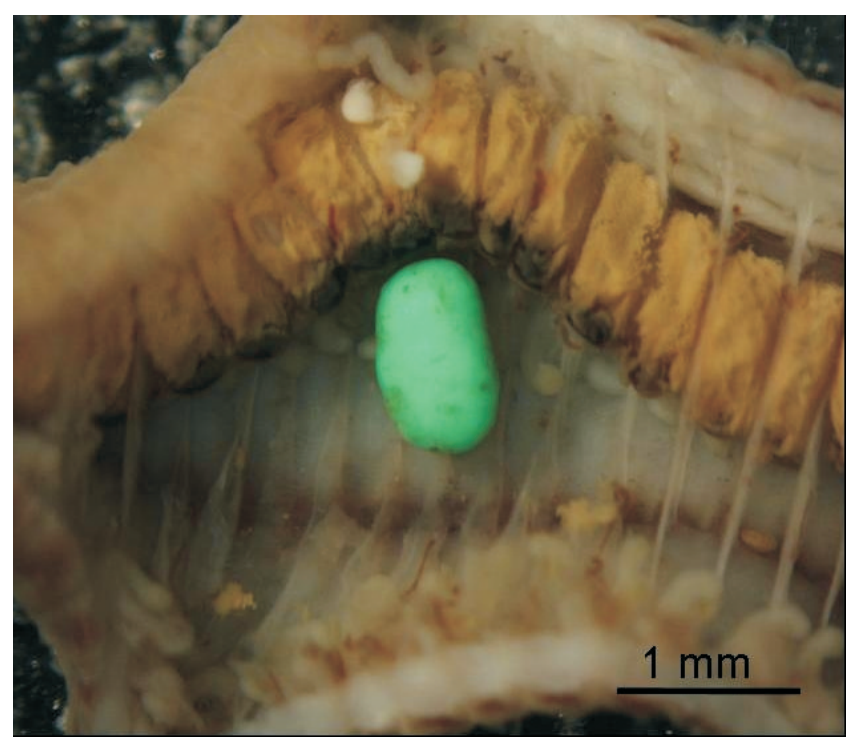

Figure 1. Green tagged Eisenia andrei, viewed after a period of one month. No internal damage was caused by insertion of the tag into the animal, and minimal wrapping of the tagging material is observed.

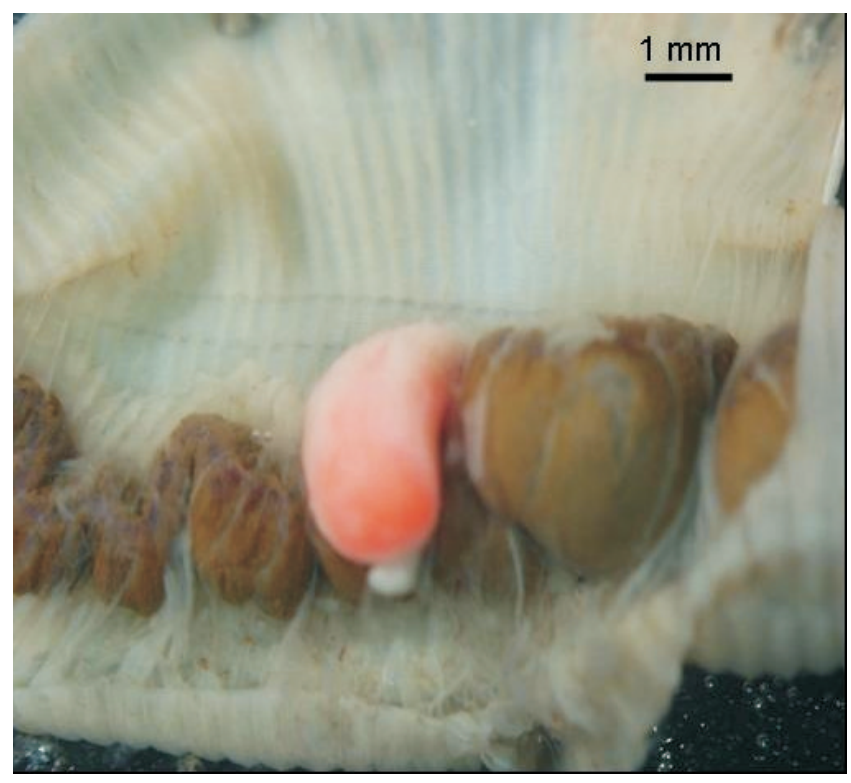

Figure 2. Red tag clearly visible externally, after 10 months, and located within the body cavity of Octolasion cyaneum, with some adhering nephridial tissue. 
the endogeic $A$. caliginosa, which is worthy of note as published material (Butt \& Lowe, 2007) had previously only recorded viable tags for a period of 12 months. Nevertheless, on dissection the tag material present within the body of A. chlorotica showed further noteworthy traits. Firstly, the tag itself was not present as a single unit, but a large
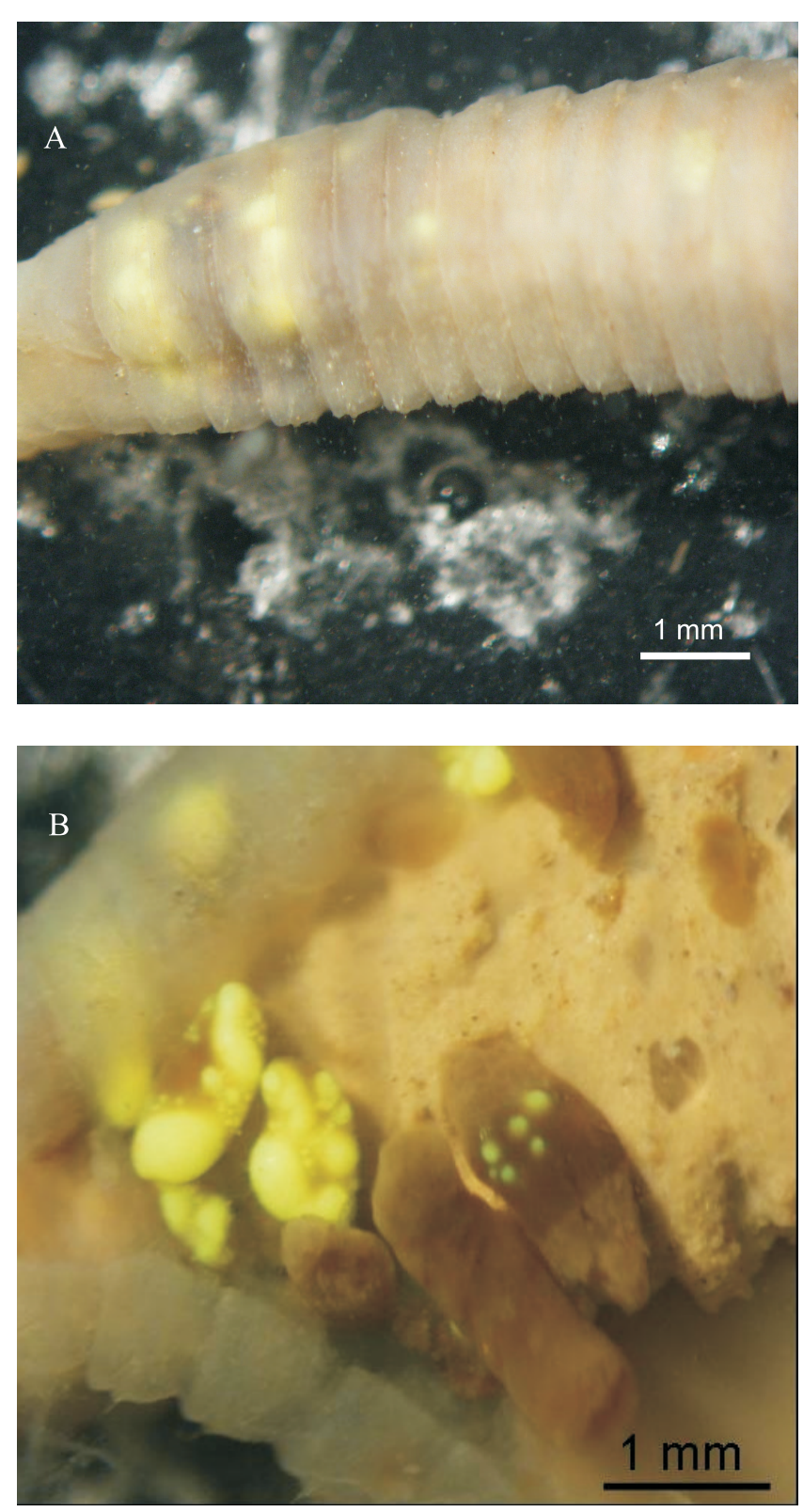

Figure 3. Yellow tagged Allolobophora chlorotica viewed after 27 months. A, yellow VIE colouration is still clearly visible through the body wall; $\mathrm{B}$, dissected specimen showing smaller "scatter tags" and encapsulation of some tagging material by the chlorogogenous tissue. number of small "scatter tags" (Figure 3 B). One possible reason for this may have been that the animal tagged was relatively small at the time of tagging $(0.1 \mathrm{~g})$ making it a small target. No evidence of sharp edges, suggesting fracturing of the tag, was discerned under the dissecting microscope. A similar result was obtained with a number of the smaller E. andrei, in which scattering of green tags suggested that the size of animal, in proportion to diameter of hypodermic, could be an important factor to take into account when tagging small-sized species or juveniles.

Dissection of these long-term tagged worms showed another important aspect to be considered, which was encapsulation of the smallest droplets of VIE material by chloragogenous tissue, so that they were difficult to see through the body wall prior to dissection (Figure $3 \mathrm{~B}$ ). This may have implications for potential long-term experiments with earthworms and VIE. Similarly, the yellow VIE, 27 months after injection into L. terrestris (Figure 4), had also become partially wrapped by the chlorogosomes. However, in this case, the larger size of the injected tag meant that it could still be seen externally in this heavily pigmented worm, both in live and preserved specimens. The peritoneal chlorogogenous cells are involved with the removal of waste products and

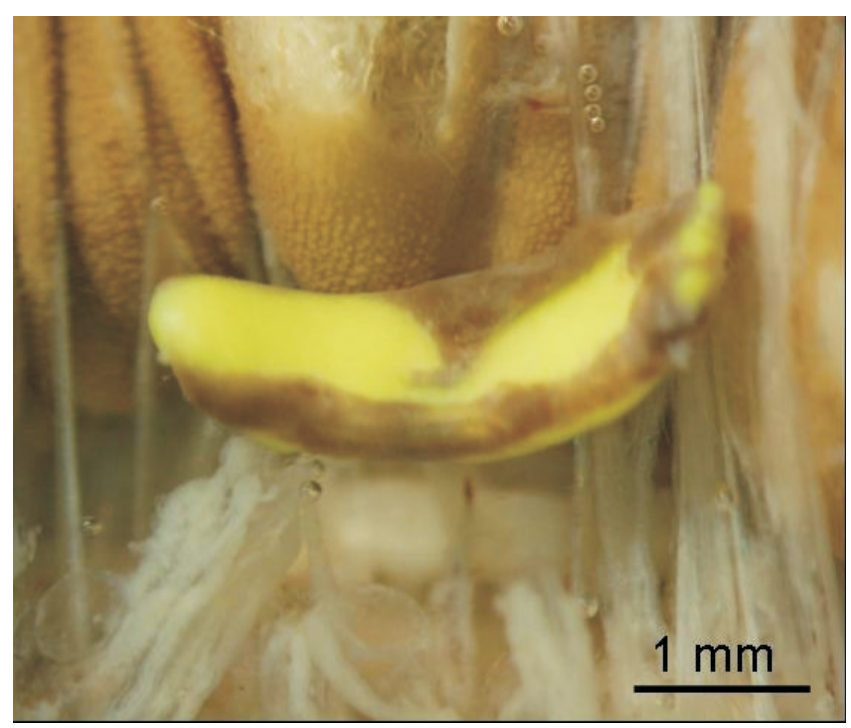

Figure 4. Yellow tagged Lumbricus terrestris after 27 months. The chloragogenous tissue has clearly begun to encapsulate the tagging material with a brown coat, making it increasingly difficult to locate externally. 
elimination of various metals, and this appears to be a detoxification strategy preventing dissemination of large concentrations of foreign substances into other earthworm tissues (Spurgeon \& Hopkin, 1996; Morgan \& Morgan, 1998; Langdon et al., 2001). It is suggested that in some species such encapsulated materials are wafted posteriorly in the coelom, via mid-ventral foramena in the septa to the caudal region, for storage to potentially await autotomy (Sims \& Gerard, 1999). This type of behaviour might help to explain why tags administered posterior to the clitellum have been reported to migrate towards the tail in previous trials (González et al., 2006; Butt \& Lowe, 2007).

Nevertheless, results showed that, although there were differences between species, the tag material tended not to become enveloped by the chloragogenous matrix in periods up to 10 months. After injection and in the longer term (e.g. after two years), the thickness of this layer (surrounding the tag) made tag location more difficult, but not impossible. This problem became more acute when the material was injected/ settled as small droplets (scatter tags) at the rear end of the body.

It is suggested that, for reliable tagging, a reasonably large amount of VIE material needs to be precisely injected into segments adjacent to, but behind the clitellum, to avoid impeding any reproductive activity. Further research is needed to determine the maximum period of time this tagged material can be observed in different species. If over time, the earthworm "encases" the tag, then, long-term monitoring using this technique may be questionable. Use of this technique for earthworm population estimation, or trials with bioavailability of soil contaminants appears sound, particularly, if conducted over a relatively short period of time. Longer trials may be hampered by posterior movement or obscuring of tags by being encapsulated by the chlorogogenous tissue.

\section{Conclusions}

1. Visual implant elastomer tags in earthworms can still be seen after 27 months.

2. The tags do not disintegrate or disrupt growth or reproduction, but migration of tags towards the posterior end of the earthworm may occur.
3. The colour of the tag used can assist or hamper visibility and is best matched to level of pigmentation in the particular earthworm species.

4. Integrity of VIE tags does not appear to be adversely affected by the species or ecological grouping of the earthworm, but smaller earthworm specimens are more difficult to administer VIE to, and "scatter tags" may result.

\section{Acknowledgements}

To the Cell Biology section (University of Vigo), for the use of their microscope and picture capturing system.

\section{References}

BEN HAMOU, M.; KULHANEK, A.; LACOMBE, S.; WHALEN, J. K. Marking earthworms for release-recapture studies using the trace element rubidium. Applied Soil Ecology, v.36, p.41-45, 2007.

BRENNAN, N.P.; LEBER, K.M.; BLANKENSHIP, H.L.; RANSIER, J.M.; DEBRULER, R. An evaluation of coded wire and elastomer tag performance in juvenile common snook under field and laboratory conditions. North American Journal of Fisheries Management, v.25, p.437-455, 2005.

BUTT, K.R.; LOWE, C.N. A viable technique for tagging earthworms using visible implant elastomer. Applied Soil Ecology, v.35, p.454-457, 2007.

DYCKMANS, J.; SCRIMGEOUR, C.M.; SCHMIDT, O. A simple and rapid method for labelling earthworms with ${ }^{15} \mathrm{~N}$ and ${ }^{13} \mathrm{C}$. Soil Biology and Biochemistry, v.37, p.989-993, 2005.

GODIN, D.M.; CARR, W.H.; HAGINO, G.; SEGURA, F.; SWEENEY, J.N.; BLANKENSHIP, L. Evaluation of a fluorescent elastomer internal tag in juvenile and adult shrimp Penaeus vannamei. Aquaculture, v.139, p.243-248, 1996.

GONZÁLEZ, G.; ESPINOSA, E.; LIU, Z.; ZOU, X. A fluorescent marking and re-count technique using the invasive earthworm Pontoscolex corethrurus (Annelida: Oligochaeta). Caribbean Journal of Science, v.42, p.371-379, 2006.

LANGDON, C.J.; PIEARCE, T.G.; MEHARG, A.A.; SEMPLE, K.T. Resistance to copper toxicity in populations of the earthworms Lumbricus rubellus and Dendrodrilus rubidus from contaminated mine wastes. Environmental Toxicology and Chemistry, v.20, p.2336-2341, 2001.

MAZAUD, D.; BOUCHÉ, M.B. Introductions sur population et migrations de lombriciens marqués. In: INTERNATIONAL SOIL ZOOLOGY COLLOQUIUM, 7., 1979, Syracuse. Soil biology as related to land use practices: proceedings. Washington: EPA, 1980. p.687-701. 
MORGAN, J.E.; MORGAN, A.J. The distribution and intracellular compartmentation of metals in the endogeic earthworm Aporrectodea caliginosa sampled from an unpolluted and a metal-contaminated site. Environmental Pollution, v.99, p.167-175, 1998.

NORTHWEST MARINE TECHNOLOGY. Visible implant elastomer tags (VIE). Available at: $<$ http://www.nmt.us/products/ vie/vie.htm>. Accessed on: 15 Sept. 2008.
SIMS, R.W.; GERARD, B.M. Earthworms. Shrewsbury: Field Studies Council, 1999, 169p. (Synopsis of the British Fauna, 31). SOUTHWOOD, T.R.E.; HENDERSON, P.A. Ecological methods. $3^{\text {rd }}$ ed. Oxford: Blackwell Science, 2000. 575p.

SPURGEON, D.J.; HOPKIN, S.P. The effects of metal contamination on earthworm populations around a smelting works: quantifying species effects. Applied Soil Ecology, v.4, p.147-160, 1996.

Received on September 29, 2008 and accepted on July 6, 2009 